\title{
REINTERPRETACIÓN DE NIEBLA: EL CARÁCTER DE LA COMUNICACIÓN LITERARIA
}

Cuando leemos una novela tradicional (del siglo XIX) adoptamos una actitud lectora bastante menos activa que cuando nos enfrentamos con una ficción moderna - Julio Cortázar hablaba a este respecto de lectores cómplices, de camaradas de camino o de copartícipes en la creación. Se trata, entre otras cosas, de que el escritor del siglo pasado construía el mundo novelesco con autoridad, trazando sin ambages las coordenadas morales y éticas vigentes en la sociedad donde habitan los seres de ficción, mientras, por contraste, el artista de nuestro siglo ha abandonado las seguridades autoritarias del decimonónico para crear un mundo sustentado por un yo, por una personalidad autorial que no se forja en las reglas establecidas por la sociedad en la que escribe, sino en sus propias deducciones, disquisiciones. Diríamos, exagerando un poco, que el escritor pasó de actuar como portavoz a ser una persona. A Unamuno este último estereotipo le encaja a la perfección, pues el profesor de Salamanca era, y bien lo sabemos, el yoísta por excelencia.

Sin profundizar en las múltiples diferencias existentes entre ambos modelos de novelistas, del XIX y del xx, lo que obligaría a matizar con menos temeridad, quisiera examinar simplemente la idea apuntada, la de la falta de autoridad, insistiendo en que la potestad autorial del portavoz-narrador decimonónico no radica por lo general en sus propias cualidades, sino en las que representa, que son con frecuencia valores ético-sociales. De éstos proviene la jurisdicción significativa de la narrativa del ochocientos, lo que la hace ejemplar, adecuada para estudiar en ella los sistemas de valores de una situación social estable. Existe, pues, un lazo entre realidad y realidad textual, la referencialidad del texto es el puente por donde se trasvasa el significado ficticio. Unamuno - y la mayoría de los escritores modernos- sale de ese círculo hermenéutico, y abandona la postura autoritaria en el texto (no olvidemos que autoritario es sinónimo de arbitrario); el mundo de sus personajes era para él "más real que el de Cánovas y Sagasta, de Alfonso XIII, de Primo de Rivera... todos ellos a quienes conocí o conozco vivos" (p. 61). Entonces, si los sistemas de valores establecidos no soportan 
la ficción, ¿dónde reside ahora el poderío de la novela -expresión tomada del precioso título de Eduardo Mallea-,.y de dónde proviene?

Respuestas se han dado muchas, que varían según la postura crítica, y van desde lo filosófico hasta lo biográfico, pasando por lo estilístico. Yo pretendo contestar fijándome en cómo se ha producido una sustitución en el tipo de discurso narrativo: del basado en la transmisión de hechos verificables pasamos al que constituye su significado en la enunciación. Es decir, la significación nace en el decir no en la representación que implica lo que se dice. Comenzaré la labor poniendo en el objetivo analítico a Niebla, en concreto a la famosa novelita intercalada del fogueteiro; leamos el texto de Unamuno (habla Augusto Pérez):

-Allá voy. Pues el caso es que había en un pueblo portugués un pirotécnico o fogueteiro que tenía una mujer hermosísima que era su consuelo, su encanto y su orgullo. Estaba locamente enamorado de ella, pero aún más era orgullo. Complacíase en dar dentera, por así decirlo, a los demás mortales, y la paseaba consigo como diciéndoles: ¿veis esta mujer?, ¿os gusta?, ¿sí, eh?, ¡pues es la mía, mía sola!, iy fastidiarse! No hacía sino ponderar las excelencias de la hermosura de su mujer y hasta pretendía que era la inspiradora de sus más bellas producciones pirotécnicas, la musa de sus fuegos artificiales. Y hete que una vez, preparando uno de éstos mientras estaba, como de costumbre, su hermosa mujer a su lado para inspirarle; se le prende fuego la pólvora, hay una explosión y tienen que sacar a marido y mujer desvanecidos y con gravísimas quemaduras. A la mujer se le quemó buena parte de la cara y del busto, de tal manera que se quedó horriblemente desfigurada, pero él, el fogueteiro, tuvo la fortuna de quedarse ciego y no ver el desfiguramiento de su mujer. Y después de esto seguía orgulloso de la hermosura de su mujer y ponderándola a todos y caminando al lado de ella, convertida ahora en su lazarilla, con el mismo talle de arrogante desafío de antes. "¿Han visto ustedes mujer más hermosa?", preguntaba, y todos, sabedores de su historia, se compadecían del pobre fogueteiro y le ponderaban la hermosura de su mujer (p. 138).

Antes de proseguir conviene añadir una referencia textual de suma importancia, las circunstancias por las que Augusto relata la historia del pirotécnico portugués, su enmarcado. Hallándose en diálogo con Víctor Goti, éste le participó el nacimiento de su hijo, calificando el estado en que ha quedado la esposa tras el parto en los siguientes términos: "Tan ciego estoy, que todos dicen que mi Elena ha quedado con la preñez y el parto desfiguradísima, que está hecha un esqueleto y que ha envejecido lo menos diez años, y a mí me parece más fresca, más lozana, más joven y hasta más metida en carnes que nunca' (p. 138). Evidentemente, la confesión contiene una situación enunciativa dual, el "a mí me parece" (bella) versus el "dicen ellos" que está esquelética, mediante la que se enfrenta la advertencia subjetiva a la proposición objetiva. La ceguera resulta, pues, una imagen que sirve para presentar, justificar una perspectiva que no necesita confirmación de los sentidos. Víctor siente hermosa a su mujer y basta.

La invidencia de Víctor le recordará a Augusto la historia del por- 
tugués, no tanto por el aspecto temático de cómo los sentidos confunden nuestras percepciones y al hacerlo dejan al descubierto una verdad más profunda, sino, como indicaré muy pronto, por las implicaciones verbales de lo contado. Regresemos antes a la confesión de Víctor; si consideramos la situación narrativa pragmáticamente, deberemos concluir que ese "a mí me parece [Elena] más fresca, más lozana, más joven y hasta más metida en carnes que nunca" es un espejismo, o mejor dicho, son unas palabras a las que les falta el respaldo de "la realidad" (en la pragmática del texto). El hecho es que Elena ha quedado muy desmejorada del parto. La frescura y la lozanía, la juventud y la firmeza de las carnes, a pesar de sus fuertes connotaciones referenciales son meras palabras, una invención de Víctor. Además de haber aquí dos perspectivas, asistimos al enfrentamiento de dos lenguajes, el que comprueba "la realidad" y otro distinto que la inventa. Víctor inventa una realidad no comprobable, la belleza de su mujer (cuando las apariencias dicen lo contrario), a la vez que va socavando la referencialidad de términos como lozanía o juventud, los va, si se quiere decir, dessensitivizando, desprendiéndolos de las apreciaciones sensoriales comunes, que el lector lleva consigo a todo texto, y creando una sensitividad dependiente de lo subjetivo, del "a mí me parece". Asistimos así a la transferencia de autoridad; el poder significativo emana ahora de la manera en que se crea el sentido en el texto, enunciable de la siguiente forma: "aunque a la gente le parezca inverosímil, Elena está bellísima tras el parto". Esta afirmación no depende de criterios impuestos desde fuera, nace en el propio texto, le es inherente.

Llevando el análisis de la confesión de Víctor un poco más lejos, y si la leemos desde la perspectiva de la creación del personaje, la interpretación varía algo y ofrece una idea complementaria. Ese Elena "está hecha un esqueleto" al que se superpone el "a mí me parece [...] más metida en carnes" muestra a Víctor re-constituyendo al ser de ficción mediante un acto de la mente. Su voluntad dota al huesudo esqueleto de carne y tejido corporal. Por lo tanto, el texto contiene la Elena para los otros y la Elena para Víctor; esta última es, diríamos, un fantasma puramente textual. Los lectores tenemos que tener en cuenta a ambos: el comprobable mediante los sentidos y el no comprobable o subjetivo. Orfeo aclara el dilema planteado al final de la novela, por si acaso no lo entendimos: "[el hombre] habla, y eso le ha servido para inventar lo que no hay y no fijarse en lo que hay" (p. 182).

Todo esto nos lleva a reconocer la primacía del texto, a reconocer que él sustenta el mundo que contiene, que el poder significativo de la novela emana de su propio tejido verbal. El concepto de autoridad, con sus connotaciones jurídicas, resulta pues inadecuado al considerar un texto moderno; el "a mí me parece" no es susceptible de ser considerado bajo el criterio de verdad o mentira; el aplicar la lógica para explicarlo tampoco ayuda nada, hay que utilizar un criterio pragmático, fijarse en su ocurrencia, en el hecho de que es una acción discursiva cuyo significado se sostiene a sí mismo sin referencias al mundo mimético, está 
contenido en la enunciación misma. Elena es bella porque así lo determina quien enuncia su hermosura en el acto de decirlo. Discutir si lo es o no sería aplicar un criterio lógico, y aquí se trata de hacer otra cosa.

La confesión de Víctor, según ya apunté, recuerda a Augusto la leyenda del fogueteiro. Con ella el nivolesco Pérez va a añadir un elemento de suma importancia al relato de Goti, la reacción del auditorio ante una historia parecida. Cuando digo auditorio me refiero, en principio, al mismo Augusto (oyente original), pues él es el primer receptor de las confidencias de Víctor. Su impulso inmediato no es consolar a Víctor por su disfunción perceptiva, sino lanzarse a contar una historia. Tras transformar el adjetivo "desfiguradísima", que generó la confesión de Víctor, en "hermosísima", y en alas del superlativo, contagiado incluso por el uso de las series adjetivales ("más fresca", "más lozana", "más joven", " más metida en carnes") duplicada en "su consuelo", "su encanto", "su orgullo", se lanza a contar a Víctor un caso parecido. Uno que, al pasar la historia que Víctor daba en términos de una "confesión" a los de "leyenda", la literaturiza.

Augusto con su leyenda va a recrear lo que es aún más importante para nuestro objetivo, el tipo de discurso de Víctor, añadiéndole su actitud de receptor del mismo. Y creo que esta respuesta, que en seguida analizaremos, constituye uno de los elementos esenciales en todas las novelas intercaladas de Niebla, incluida la presente, al situar a Augusto de primer oyente de una acción discursiva "performativa" (acción mediante la que no se describe nada ajeno al acto de la enunciación) predomine sobre la "constativa" (la que representa un acontecimiento o estado de cosas, que puede ser verdadero o falso). Sirva la inclusión de dos breves ejemplos para recordarnos la diferencia entre "performatividad" y "constatividad"; un ejemplo de la primera - que ofrece Gonzalo Abril- sería “'Os declaro marido y mujer'. Aquí no hay nada que se puede constatar, las meras y simples palabras son lo que une a la pareja en matrimonio, acción bien distinta de la que efectuamos al decir "El perro está en el jardín", lo cual puede ser cierto o no, cabe la comprobación.

Iniciemos el comentario de la recepción textual repasando el enfrentamiento del discurso "constativo" con el "performativo", tal y como acabamos de hacer con la confesión de Víctor, en la leyenda narrada por Augusto. La belleza de la esposa del pirotécnico antes del incendio viene, en principio, afirmada: "tenía una mujer hermosísima". La frase aparece respaldada por la autoridad retórica del texto, evidenciada en frases como "el caso es que", o "por así decirlo", y "hete aquí que", "y después de esto", que sustentan la proposicionalidad de la leyenda, son los cimientos enunciativos. Cuando tras el fuego el pirotécnico pregunta a cuantos halla en su camino sobre los encantos de la esposa para que los certifiquen, y éstos lo hagan a pesar de no ser verdad, queda claro que la acción discursiva ha rebasado la lógica; al responder no contestan ateniéndose a si es verdadera o falsa la pregunta, se ajustan a otros criterios. El adjetivo "hermosa" de la frase " ¿Han visto ustedes 
mujer más hermosa?" pasa de ser algo que se puede constatar en el texto mismo a ser una creación del ciego; no se certifica la hermosura; el pensamiento, el deseo, la voluntad, o si se prefiere, el orgullo del marido son los que la hacen hermosa.

Cuando el fogueteiro interroga al auditorio acerca de la belleza de su cónyuge - y repito- esa interrogación es además la expresión de su orgullo y la afirmación de un deseo, o sea que el sentido que tradicionalmente asignamos a una interrogación viene aquí recargado por una fuerza distinta, parecida o complementaria a la observable en la acción discursiva empleada por Víctor para afirmar la belleza de su esposa. En consecuencia, al igual que la lengua pierde su función instrumental, la interrogación pierde la suya para hacerse afirmación. En realidad, el fogueteiro no pregunta, es una mera cuestión retórica, lo que hace es confirmar con sus palabras la belleza, o aún mejor, crearla. El acto de preguntar si es hermosa la hace bella, y esa beldad es la que se ve aceptada por el auditorio, "le ponderaban la hermosura de su mujer". La respuesta del auditorio autentifica la belleza sin utilizar el valor instrumental del lenguaje, sino que se sirve del "performativo".

En resumidas cuentas, no es que Unamuno emplease un lenguaje menos realista, pues no existe un lenguaje menos realista, sino que el discurso, la coloración, la forma personal con quien habla en un texto matiza la fábula, la historia contada, emplea un tipo de discurso que prefiere a otro. Lo cual, a su vez, supone que la autoridad en la novela no reduplica la existente en el mundo social, como ocurre en la narrativa del XIX, donde el tipo de discurso predominante tendía a afirmar algo exterior al texto. Podemos decir que la novela del XIX tendía a olvidar la inclusión de una frase, tan simple como "yo pienso" o "yo opino", con cuya inserción cualquier afirmación se relativiza, se convierte en "performativa". Dicho de forma distinta, en el discurso realista predomina la "constatividad" debido a la supresión de la posibilidad "performativa".

La autoría en la novela moderna rompe el puente que une la realidad social con la creada al no permitir ese trasvase de valores reflejados en la conducta social. Cuando Augusto Pérez traspasa el umbral de la ficción para entrar en el de la metaficción - en la famosa escena en que se encuentra con Unamuno, su creador-, abandona cualquier posibilidad de verificación del mundo ficticio para entrar en una vía explicativa, en la preocupación de la existencia de esa realidad ficticia que acaba de abandonar. La metaficción resulta una vía parentética, es una explicación o es el espacio discursivo metaficticio donde se busca una explicación al ficticio. Augusto busca su ser en las palabras, en la creación verbal, o dicho de otra manera, pretende luchar cuerpo a cuerpo con el creador, con el Verbo que le dio vida, que es donde se refugia ahora la autoridad. Así pues, la autoridad, el sentido del poder sobre la existencia de Augusto se ha ido hacia lo parentético, hacia lo metaficticio, donde el autor afirma su voluntad creadora.

$\mathrm{Y}$ eso es lo que Unamuno hace en todas sus intervenciones metafic- 
ticias en esta novela, afirmar su voluntad. Desde el post-prólogo, donde disputa con Víctor sobre si fue un suicidio o no la muerte de Augusto, las intrusiones hechas en off ("Y yo soy el Dios de estos dos pobres diablos nivolescos [Augusto y Víctor]", p. 153). Claramente al bautizarse Dios a sí mismo está efectuando un acto "performativo", se está nominando a sí mismo, mas lo hace, como ya dije, en off, en un paréntesis, se afirma en el poder creador de la mente del autor, no los del reflector. Los comentarios metaficticios en Niebla son, en última instancia, reflejos de la conciencia, y el equivalente del "yo pienso", "yo opino", que parentéticamente incluimos en la escritura.

Es decir, la metaficción en Unamurio no resulta un juego libre, como lo es en Cortázar o en Julián Ríos, sino que es un cuestionamiento de la existencia de las verdades. Y si consideramos el aspecto metaficticio de la obra a la par con el contraste de dos tipos de discurso en la ficción unamuniana, aquí ejemplificados en una ejemplar novela intercalada, creo que podemos llegar a una conclusión significativa. Unamuno no sólo estaba contrastando en sus novelas el concepto del ser de ficción frente al real (la interpretación más aceptada de sus novelas), ni la ficción frente a la metaficción (la exégesis de mayor aceptación hoy en día), sino que también estaba contraponiendo los dos tipos de acción discursiva de que nos valemos, haciendo que predomine en su escritura el "performativo", el que prescinde del mundo exterior y se apoya más en lo subjetivo. $\mathrm{Y}$ ahí vemos cómo la autoridad en la ficción se desplaza, la acción discursiva de la novela moderna se apoya en acto discursivo personal, que incluso calificamos de parentético, que no ofrece al lector ninguna seguridad, por eso, y como vimos en la historia del fogueteiro, hasta nuestra respuesta al mismo tiene que ser distinta, no basada en las certezas representacionales de la palabra, sino en las que nuestra voluntad, deseo e inteligencia son capaces de forjar con el verbo. Si algún poder tiene el autor moderno le viene del "Verbo que fue el principio y será el último, el Soplo y don espiritual que recoge las nieblas y las cuaja"' (p. 62).

Germán Gullón

University of Pennsylvania 